\title{
Optimization and performance of a small scale adsorption cooling system fully powered by solar energy for hot arid areas
}

\author{
Ahmed M. Reda ${ }^{1} \cdot$ Ahmed Hamza H. Ali ${ }^{2} \cdot$ Mahmoud G. Morsy ${ }^{2} \cdot$ Ibrahim S. Taha $^{2}$
}

(C) Springer Nature Switzerland AG 2019

\begin{abstract}
The aim of this study is to identify the optimal design parameters of a fully solar-powered adsorption cooling system for residential buildings located in hot arid areas. The proposed system consists of solar collectors, hot water tank, watersilica gel adsorption chiller of $8 \mathrm{~kW}$ cooling capacity, cold water tank, fan coil unit, and cooling tower. An optimization based on computer simulation has been conducted for achieving the aim of this study. The proposed system was applied to Assiut, Egypt as a case study. The optimization shows that the optimal design parameters of the proposed system are as follows: $58 \mathrm{~m}^{2}$ solar collecting area, $5.5 \mathrm{~m}^{3}$ hot water tank and $1 \mathrm{~m}^{3}$ cold water tank. The simulation of the proposed system with the optimal design parameters during the design day shows that the chilled water temperature leaving the chiller is between 17 and $18{ }^{\circ} \mathrm{C}$ with high cooling water temperature of $34.5^{\circ} \mathrm{C}$. This makes the system unable to achieve the indoor thermal design conditions. However, the system is able to meet the cooling demand in most days of the cooling season except for about $9.15 \%$ representing extreme hot days. The simulation also shows that during the design day, the proposed system achieves daily solar collecting efficiency of $56 \%$ and can produce chilling energy of $113.3 \mathrm{kWh}$ with $7.35 \mathrm{~kW}$ energy rate and daily COP of 0.41 . In addition, the cold water tank enables the system to extend the operation period for $110 \mathrm{~min}$ after switching off the chiller.
\end{abstract}

Keywords Solar cooling · Adsorption · Residential scale · Optimization

\section{List of symbols}

$\dot{m}_{c} \quad$ Collector's mass flow rate, $\mathrm{kg} / \mathrm{s}$

$F_{i}^{c} \quad$ Control function of the collector flow rate

$F_{i}^{l} \quad$ Control function of the load return flow rate

$\dot{m}$ Mass flow rate, $\mathrm{kg} / \mathrm{s}$

A Area, $\mathrm{m}^{2}$

AARE Average absolute relative error

$C O P$ Coefficient of performance

$c_{p w} \quad$ Specific heat of water, $\mathrm{kJ} / \mathrm{kg} \mathrm{K}$

$G_{T} \quad$ Incident solar radiation upon the collector surface, $W / \mathrm{m}^{2}$

$m \quad$ Mass, $\mathrm{kg}$

$n \quad$ No. of measurements

$q \quad$ Rate of energy, $W$

$q_{\text {inter }} \quad$ Energy exchange function between nodes

$T \quad$ Temperature, ${ }^{\circ} \mathrm{C}$
$T_{c i} \quad$ Inlet collector temperature, ${ }^{\circ} \mathrm{C}$

$T_{c o} \quad$ Outlet collector temperature, ${ }^{\circ} \mathrm{C}$

$T_{l, r} \quad$ Temperature of the water returns from the load circuit, ${ }^{\circ} \mathrm{C}$

$T_{s, i} \quad$ Temperature of node $i$

$T_{s, i} \quad$ Temperature of node $\mathrm{i},{ }^{\circ} \mathrm{C}$

$U$ Overall thermal loss coefficient, $\mathrm{W} / \mathrm{m}^{2} \mathrm{~K}$

$x_{m} \quad$ Measured value

$X_{\mathrm{s}} \quad$ Simulated value

Greek symbols

$a_{0} \quad$ Intercept of the solar collector efficiency

$a_{1} \quad$ Negative of the first order coefficient, $\mathrm{W} / \mathrm{m}^{2} \mathrm{~K}$

$a_{2} \quad$ Negative of the second order coefficient, W/ $\mathrm{m}^{2} \mathrm{~K}^{2}$

$\eta_{c} \quad$ Thermal efficiency of the solar collectors

$\tau \quad$ Time, $\mathrm{s}$

$\triangle$ Ahmed M. Reda, ahmedh_78@yahoo.com | 'Department of Mechanical Power Engineering, Faculty of Energy Engineering, Aswan University, Aswan 81528, Egypt. ${ }^{2}$ Department of Mechanical Engineering, Faculty of Engineering, Assiut University, Assiut 71516, Egypt. 


\begin{tabular}{ll}
\multicolumn{2}{l}{ Subscripts } \\
abs & Absorbed \\
$a m b$ & Ambient \\
$a v g$ & Average \\
$c$ & Collector \\
$c h$ & Chilling \\
$c h w$ & Chilling water \\
$c w$ & Cooling water \\
$d h$ & Driving heat \\
$h w$ & Hot water \\
$i$ & Node i \\
in & Inlet \\
I & Load circuit \\
$m$ & Mean \\
out & Outlet \\
$s$ & Storage tank \\
sol & Solar
\end{tabular}

\section{Introduction}

In the hot and arid areas, most of the energy consumed in residential buildings is used to achieve internal thermal comfort conditions. The use of conventional air conditioners for this purpose has a detrimental effect on the environment as it increases emissions of greenhouse gases as well as components of HFCs and HCFCs that cause Depletion of the ozone layer.

Promising technologies have emerged recently in air conditioning. In these technologies, renewable energy sources are used as an alternative source to drive the air conditioning systems for reducing the conventional energy consumption consequently the harmful gas emissions. Solar cooling as one of these technologies has an advantage in hot and arid areas because of the near coincidence of peak building cooling load with the available solar irradiation.

Solar adsorption cooling as one of solar cooling technologies has been developed more rapidly in research and technical development than other solar cooling systems and is considered as a good option comparing with the other types of solar cooling systems [4]. This is because the adsorption cooling systems can be driven by somewhat lower and wider range of temperatures, in addition to the other features of adsorption systems such as no need for a liquid pump for the refrigerant and noiseless and environmentally friendly operation. For small capacity chillers, solar adsorption cooling systems are thought to be more promising in mini-type building air conditioning systems $[3,18,21,22]$. Several types of working pairs are used in solar adsorption cooling. Some of these are water-silica gel, methanol-activated carbon, water-zeolite, and etc. Water-silica gel pair is more suitable for air conditioning purposes where silica gel can regenerate at low temperature, achievable with simple flat plate or evacuated tube collectors and water is considered to be an ideal refrigerant with no environmental harm and no toxicity $[7,19]$.

In the literature, there are numerous investigations carried out on the performance of solar-powered adsorption cooling systems. Zhai et al. [23] and, Zhai and Wang $[21,22]$ designed and constructed, in Shanghai, (China), a solar driven cooling system with two small water-silica gel adsorption chillers of $8.5 \mathrm{~kW}$ nominal capacity for each powered by an evacuated tube solar collector field of area $150 \mathrm{~m}^{2}$. Also, a hot water storage tank of $2.5 \mathrm{~m}^{3}$ in volume was integrated with the system. The experimental results showed that the average cooling capacity was $15.3 \mathrm{~kW}$ while the daily average system COP was 0.35 . Zhai et al. [20] analyzed the performance of a solar hybrid heating, cooling and power generation system with the water-silica gel adsorption chiller. They reported that this system could have higher solar energy conversion efficiency than the conventional solar thermal power generation system alone. They added that the energy efficiency of this system increased from 10.2 to $58 \%$. El Fadar et al. $[9,10]$ studied theoretically a solar driven ammonia-activated carbon adsorption cooling system in which a solar parabolic trough collector has been introduced to overcome the intermittent character of the solar adsorption cooling systems. The predicted results illustrated the ability of the proposed system to achieve a higher performance comparing with other systems driven by either flat plate or evacuated tube solar collectors. Chang et al. [5] designed and constructed a solar-powered compound system for heating and cooling in Chinchu, (Taiwan). The system included a silica gel-water adsorption chiller of $10 \mathrm{~kW}$ cooling capacity with plate fin and tube heat exchangers, $108.5 \mathrm{~m}^{2}$ flat plate solar collectors and a hot water storage tank of $1.3 \mathrm{~m}^{3}$ in volume used as heat source to drive the chiller and also to provide hot water for heating purposes. The field tests showed that the collector field efficiency lies between 18.5 and $32.4 \%$ with an average value of $27.3 \%$. The daily COP value of the adsorption chiller lies in the 0.338-0.497 range with an average COP of 0.403 and average cooling power of $7.79 \mathrm{~kW}$. Ferreira Leite et al. [12] presented the characterization and the pre-dimensioning of a solar adsorption chiller as part of a $20 \mathrm{~kW}$ air conditioning central unit for cooling a set of rooms that comprises an area of $110 \mathrm{~m}^{2}$. In this system, the chilled water is produced during night-time by an activated carbonmethanol adsorption chiller and then stored in a tank to create a cold air during day-time. Solar energy is used for regenerating the adsorbent medium using flat plate collectors. Thermal energy is stored in a hot water tank so as to feed the chiller at night. Considering the mean value of the daily solar radiation in João Pessoa (Brazil) and a cover 
of regenerating heat supplied by solar energy equivalent to $70 \%$, they found that the expected chiller COP was around 0.6 . Lu et al. $[13,14]$ investigated the performance of both solar driven vacuum valve water-silica gel adsorption chiller and water-LiBr absorption chiller installed in the north of China. The system was driven by evacuated tube compound parabolic solar collectors. They reported that the adsorption chiller can provide $15^{\circ} \mathrm{C}$ of chilled water with average solar COP of the system of 0.16 when the chiller is driven by low-temperature hot water of $55^{\circ} \mathrm{C}$, whereas the absorption chiller can provide $15^{\circ} \mathrm{C}$ of chilled water with average solar COP of 0.19 when it powered by hot water with a temperature of $80^{\circ} \mathrm{C}$. Alam et al. [2] analytically investigated the performance of a solar driven water-silica gel adsorption cooling system for the climatic conditions of Tokyo, Japan. They found that 15 collectors of $2.415 \mathrm{~m}^{2}$ each are required to drive the adsorption chiller. They also observed that the solar-driven adsorption chiller provides cooling capacity around $10 \mathrm{~kW}$ at noon with base run conditions, while solar COP around 0.3 was achieved. Mitra et al. [15] numerically investigated the effect of cycle time, chilled water inlet and heat source temperatures on the performance (specific cooling capacity (SCC), specific daily water production (SDWP) and coefficient of performance (COP)) of a two-stage, 2-bed water-silica gel adsorption system for simultaneous generation of cooling power and potable water. The results of this study showed that decrease in heat source temperature not only reduces the specific throughput but also increases the optimum cycle time, whereas COP is relatively insensitive to such alterations. Choudhury et al. [6] studied the performance of a two bed water-silica gel adsorption chiller driven by hot water from a solar thermal collector system for two different climatic locations in India. The authors observed that the solar driving hot water temperature obtained in the composite climate of Delhi can run the basic adsorption cooling cycle efficiently throughout the year, whereas, the monsoon months of July and August in the warm and humid climate of Durgapur are unable to supply the required driving heat.

Few studies have been conducted on solar adsorption cooling for hot and arid sites such as the Middle East and North Africa, although this region is characterized by sunny and clear weather most days of the year. El-Sharkawy et al. [11] theoretically investigated the performance of solar-powered silica-gel water adsorption cooling system working under the climatic conditions of three cities in the Middle East region: Cairo, Aswan, and Jeddah. In this study they considered two system configurations; in the first one, the adsorption chiller is directly connected to compound parabolic solar collectors, meanwhile, in the second, hot water storage tank is installed as a buffer between the adsorption chiller and solar collectors.
The results showed that the system with hot water storage tank has less fluctuating cooling energy production compared to that of the system without hot water tank. Moreover, the system with hot water storage tank has the higher average daily cooling capacity and average daily COP. The authors concluded that solar driven adsorption cooling systems had promising potential applications in the Middle East region because of the advantage of abundant solar energy availability and the extended daily sunny hours during the summer. Alahmer et al. [1] theoretically studied the Performance of a residential solar-driven adsorption cooling system under climatic condition of Amman, Jordan. They reported that for adsorption cooling system driven by $36.22 \mathrm{~m}^{2} \mathrm{CPC}$ solar collector area, the average system COP was 0.467 while the cooling capacity was $8.46 \mathrm{~kW}$. They found that the optimal performance achieved when the system run with $30^{\circ}$ tilt angle of the CPC collectors, $1.4 \mathrm{~m}^{3}$ solar water storage tank volume, driving hot water temperature of $80^{\circ} \mathrm{C}$. Reda et al. [17] presented an optimization analysis for a residential scale solar assisted adsorption cooling system of $8 \mathrm{~kW}$ nominal capacity located in Assiut City, Egypt. Based on the solar saving approach, they concluded that the proposed system of $24 \mathrm{~m}^{2} \mathrm{CPC}$ solar collector area, $0.6 \mathrm{~m}^{3}$ hot storage tank, and $1 \mathrm{~m}^{3}$ cold storage tank with $94^{\circ} \mathrm{C}$ auxiliary heater set-point temperature can be considered as the most economically feasible solution. Also, Reda et al. [16] investigated the performance of $8 \mathrm{~kW}$ adsorption cooling system installed at the campus of Assiut University, Assiut, Egypt. The system was driven by $36 \mathrm{~m}^{2} \mathrm{CPC}$ solar collector area, with $1.8 \mathrm{~m}^{3}$ hot water storage tank and $1.2 \mathrm{~m}^{3}$ cold water storage tank. The experimental results showed that the chiller average daily coefficient of performance (COP) was 0.41 with $4.4 \mathrm{~kW}$ average cooling capacity when the cooling-water and chilled-water temperatures were about $31^{\circ} \mathrm{C}$ and $19^{\circ} \mathrm{C}$, respectively.

The objective of this study is to present the optimal design of a fully solar-driven water-silica gel adsorption cooling system for residential buildings located in a hot, arid area (Assiut City, Egypt as a case study). For achieving the objective of this work, a parametric optimization based computer simulation has been performed on the system design parameters: solar collector area, hot storage tank volume, and cold storage tank volume. Moreover, the performance of the system with optimal design parameters was investigated.

\section{Description of the proposed system}

Schematic diagrams of the proposed full solar powered water-silica gel adsorption cooling system and the adsorption chiller unit are shown in Fig. 1a, b. As shown 
Fig. 1 a Schematic diagram of the proposed small scale full solar powered adsorption cooling system. b Schematic diagram of the adsorption chiller unit

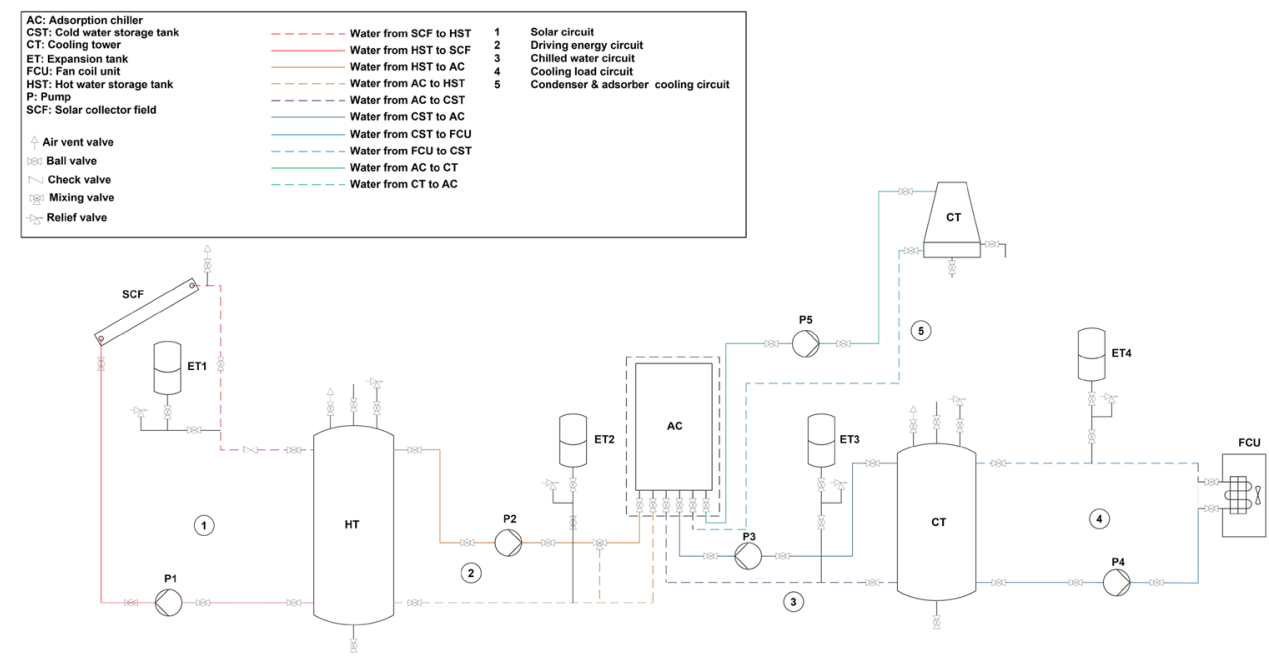

(a)

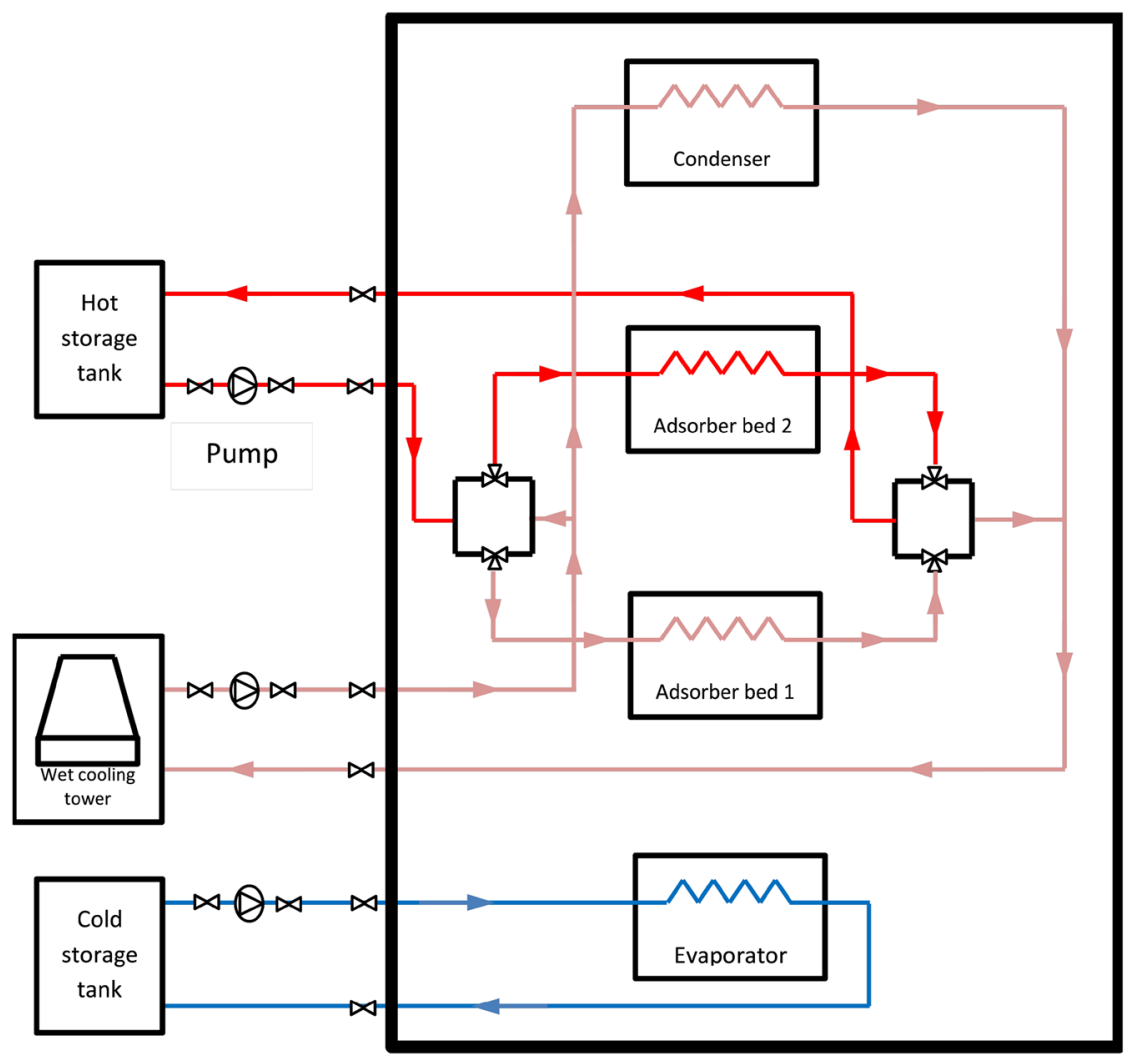

(b) in the figure, the proposed system consists of solar collector field, hot water tank, water-silica gel adsorption chiller of $8 \mathrm{~kW}$ nominal capacity, cold water tank, fan coil unit, and wet cooling tower. These components are arranged in 5 water circuits: 1 -solar circuit, 2-driving energy circuit, 3-chilled water circuit, 4-cooling load circuit, and 5-condenser and adsorber cooling circuit. The working fluid (water) in the solar circuit absorbs the solar energy incident upon the solar collectors. The absorbed solar energy is used to drive the adsorption chiller through the driving energy circuit. In the chilled water circuit, the evaporator of the adsorption chiller produces the chilled water via removing heat from the working fluid (water) carrying the building's cooling load. Then, the chilled water in the cooling load circuit is used to remove the cooling load of the building. The heat of the cooling water circulating 
in the condenser and adsorber circuit is released to the atmospheric air via the wet cooling tower. Both hot and cold water storage tanks are integrated into the proposed system as buffers to obtain more stable operating system by damping the fluctuations in the working fluid temperatures coming from the adsorption chiller. Moreover, they store the excess solar energy to be used later.

\section{Meteorological data and cooling demand}

The meteorological data generated from the typical meteorological year weather file for Assiut City is shown in Figs. 2 and 3. As shown in the figures, the site investigated has relatively hot and dry weather during the summer months: the average ambient temperature ranges between about $26.5^{\circ} \mathrm{C}$ and $30^{\circ} \mathrm{C}$, while the relative humidity is around $23.7 \%$ and $39 \%$ during the period from May to September. During the same period of the year, the monthly insolation for the inspected site exceeds $200 \mathrm{kWh} / \mathrm{m}^{2}$. This value is high enough to make use of solar cooling technology suitable to meet the cooling demand of the specified air conditioned space. Figure 4 shows the monthly cooling demand of the space to be air conditioned where it exceeds $1500 \mathrm{kWh}$ during the summer months and it reaches its maximum value during July.

\section{System modeling and validation}

The operation and the performance of the proposed solar driven adsorption cooling system were investigated by TRNSYS program (version 16). Through the TRNSYS studio, the proposed system is divided into components that are interconnected with each other. Each component is mathematically modeled by FORTRAN program. The TRNSYS

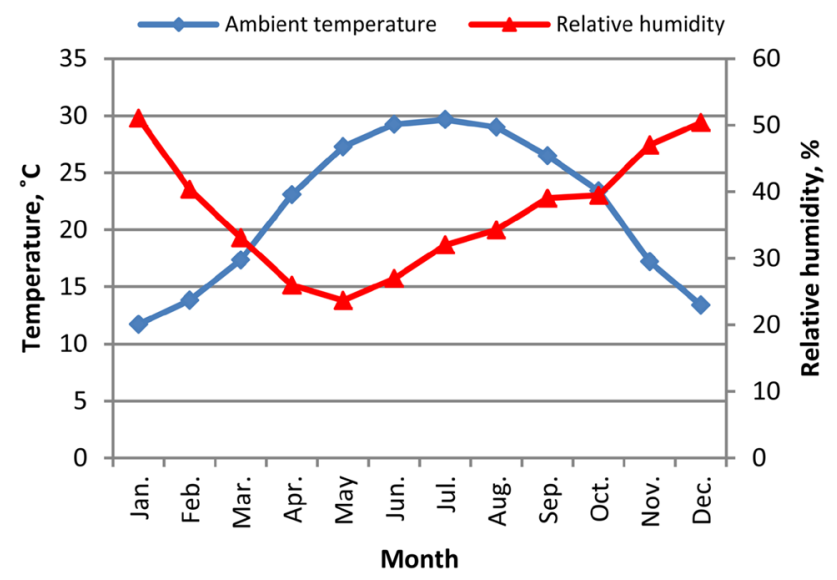

Fig. 2 Monthly average weather conditions for Assiut City, Egypt

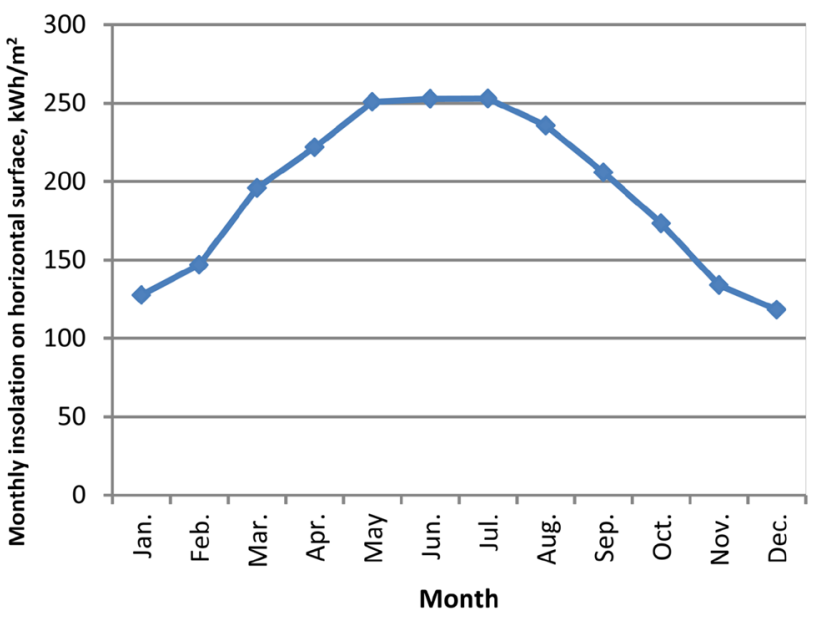

Fig. 3 Monthly insolation on horizontal surface for Assiut City, Egypt

model of the proposed solar adsorption cooling system for the present study in shown in Fig. 5. As shown in the figure, type 71 represents the evacuated tube solar collector where its mathematical model is described as follows [8]: the thermal efficiency of the solar collector and its outlet water temperature:

$\eta_{\mathrm{c}}=\alpha_{0}-\alpha_{1} \frac{\left(\mathrm{T}_{\mathrm{m}}-\mathrm{T}_{\mathrm{amb}}\right)}{\mathrm{G}_{\mathrm{T}}}-\alpha_{2} \frac{\left(\mathrm{T}_{\mathrm{m}}-\mathrm{T}_{\mathrm{amb}}\right)^{2}}{\mathrm{G}_{\mathrm{T}}}$

$T_{c, o}=\frac{\eta_{c} A_{c} G_{T}}{\dot{m}_{c} C_{p, w}}+T_{c, i}$

The values of $a_{0}, a_{1}$, and $a_{2}$ parameters are obtained from the manufacturer. Water storage tanks under

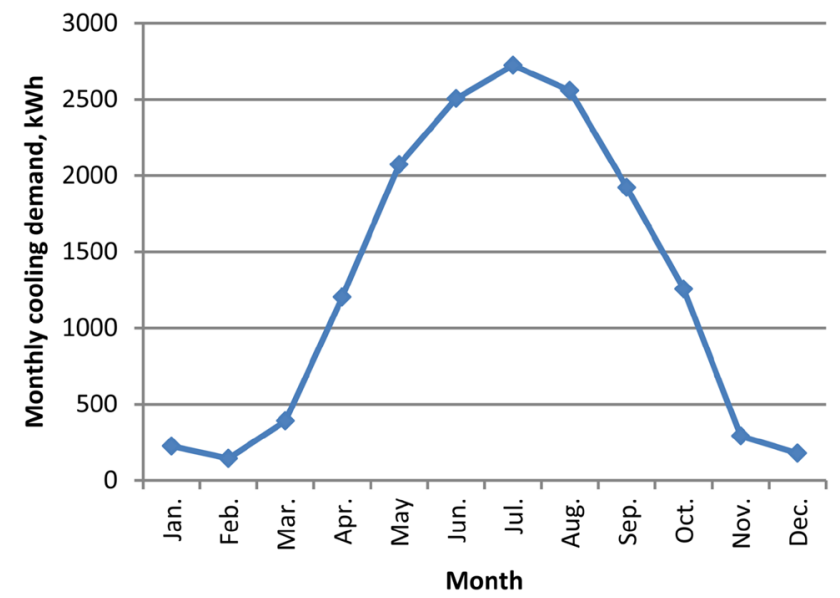

Fig. 4 Monthly cooling demand of the examined space throughout a year 


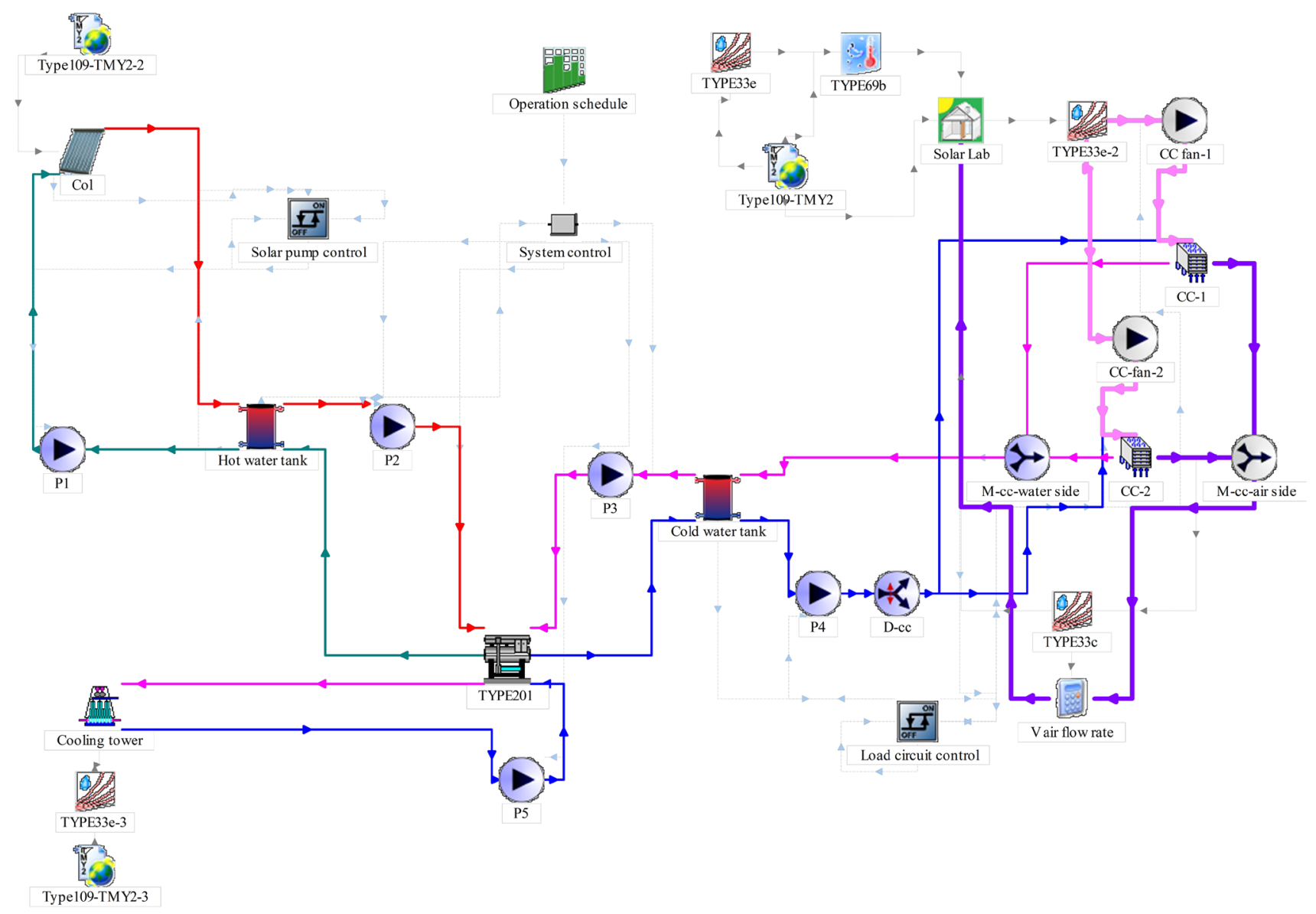

Fig. 5 TRNSYS model of the full solar driven adsorption cooling system

condiseration are considered as thermally stratified tanks which are represented in TRNSYS by type 4 . The stratified tank is modeled by dividing the tank into $N$ horizontal sections. A set of $N$ differential equations can be obtained due to energy balance for each section. The energy equation takes into account the energy gained and removed from both the supply and load circuits connected with the tank, in addition to the energy lost to the surrounding. The energy balance on a node $i$ for a thermal storage tank can be expressed as follows [8]:

$$
\begin{aligned}
m_{i} \frac{d T_{s, i}}{d \tau}= & \left(\frac{U_{s} A_{s}}{c_{p, w}}\right)\left(T_{a m b}-T_{s, i}\right)+F_{i}^{C} \dot{m}_{C}\left(T_{C, o}-T_{s, i}\right) \\
& +F_{i}^{\prime} \dot{m}_{l}\left(T_{l, r}-T_{s, i}\right)+q_{\text {inter }}
\end{aligned}
$$

where $q_{\text {inter }}$ is the energy exchange function between nodes.

Type 51 represents the wet cooling tower where flow geometry, the number of tower cells, maximum and minimum cell flow rates, fan power, and sump volume are provided. The basic geometrics of the fan coil unit including a number of rows, a number of tubes, duct height, and

\section{SN Applied Sciences}

width, inside and outside tube diameters, tube material, and fin specifications, are provided to type 52 for executing the mathematical model. The pumps are represented by type 114 which models a constant speed pump that can maintain a constant fluid outlet mass flow rate. The building simulation is conducted in TRNBUILD program which can be interfaced with TRNSYS program via type 56. TRNBUILD is a program that can simulate building transient cooling, heating; heat flows from ventilating, lighting, people, infiltration, and other internal and external heat sources. For controlling the operation of the simulated system type 2 and type 14 are used. In addition, type 109 is used for reading the required weather data file in the TMY2 format. More details concerning with these models are given in the TRNSYS manual.

In order to model the water-silica gel adsorption chiller used in the current work, means of multi-variable regression based on experimental data were applied for characterizing the chiller performance. The final regression model equations are as follows:

$\mathrm{q}_{\mathrm{ch}}=3.4713+0.0872 \mathrm{~T}_{\mathrm{hw}, \text { in }}-0.4485 \mathrm{~T}_{\mathrm{cw}, \text { in }}+0.5194 \mathrm{~T}_{\mathrm{chw}, \text { in }}$ 
$\mathrm{q}_{\mathrm{dh}}=-7.23+0.2719 \mathrm{~T}_{\mathrm{hw}, \text { in }}-0.4895 \mathrm{~T}_{\mathrm{cw}, \text { in }}+0.7225 \mathrm{~T}_{\mathrm{chw}, \text { in }}$

$\mathrm{COP}=1.0622-0.0028 \mathrm{~T}_{h w, \text { in }}-0.0229 \mathrm{~T}_{\mathrm{cw}, \text { in }}+0.0194 \mathrm{~T}_{c h w, i n}$

From the previous equations, the temperatures related to the chiller can be calculated as follows:

$$
\begin{aligned}
& T_{c h w, \text { out }}=T_{c h w, i n}-\frac{q_{c h}}{\dot{m}_{c h w} C_{p w}} \\
& T_{h w, o u t}=T_{h w, i n}-\frac{q_{d h}}{\dot{m}_{h w} C_{p w}} \\
& T_{c w, o u t}=T_{c w, i n}+\frac{\dot{m}_{c w} C_{p, w}\left(T_{c w, o u t}-T_{c w, i n}\right)}{\dot{m}_{c w} C_{p w}}
\end{aligned}
$$

The coefficient of determination $\left(R^{2}\right)$ for both the chilling power and driving heat power exceeds 0.97 . Similarly, the coefficient of determination of COP is about 0.923 . This makes the predictions obtained from the model are more reliable to be applied.

For validating the results of the dynamic simulation model, a comparison between the results of the simulation model and that obtained from the solar driven water-silica gel cooling system installed at the Campus of Assiut University, Assiut City, Egypt for a certain day of July (as shown in Fig. 6). The Average Absolute Relative Error (AARE) was used as a basis for verifying the validity of the simulation model. It is defined as follows:

AARE $=\frac{1}{n} \sum_{i=1}^{n}\left|\frac{X_{m, i}-X_{s, i}}{X_{m, i}}\right|$

Table 1 summaries the values of the AARE of the main system model parameters. Based on these values, the results of the simulation model show a good agreement with the measurements obtained from the installed solar cooling system, where most of the AARE values are less than $10 \%$ for most of the measurements except those related to the fan coil unit such as inlet and outlet chilled water of the fan coil unit. The AARE of the inlet chilled water of the fan coil unit is $11.9 \%$, and it is $17.3 \%$ for the outlet chilled water of the fan coil unit. These relatively high errors are attributed to the following: although there is thermal insulation material around the pipe lines connecting the chilled water storage tank to the fan coil unit, the length of the pipe lines longer than $20 \mathrm{~m}$ allows some heat gain throughout the pipe lines, whereas in the simulation model the heat gain throughout the pipe lines is not taken into account. In addition, the actual cooling load is slightly different from the simulated value which depends on the average meteorological data over 30 years. Thus, the dynamic simulation model can be considered as valid and reliable for monitoring the system optimization and for the system performance.

\section{System optimization}

The initial design of the proposed system based on the design criteria we used [17], shows that the main system design parameters are as follows: $60 \mathrm{~m}^{2}$ for the area of the solar collecting field, $5.9 \mathrm{~m}^{3}$ for the volume of the hot water tank, and $1 \mathrm{~m}^{3}$ for the volume of the cold water tank. Moreover, the highest value of the seasonal absorbed solar energy has been achieved whereas the solar collector field facing south is at a tilt angle of $5^{\circ}$. This angle was selected as the optimal slope of the solar collector field for the investigated site over the selected period (from May to September). Although the system can meet $96 \%$ of the targeted cooling demand, the average temperature of the hot water tank exceeds $95^{\circ} \mathrm{C}$ for long operation periods. For the permanent operation, this may cause irreversible damage to the adhesive material between the silica gel granules and the heat exchangers installed inside the adsorption chambers of the chiller. This damage can lead to a dramatical drop in the system performance. To avoid this problem and also to improve the system performance, a parametric study has been performed for obtaining the optimal values of the main system parameters: solar collecting area, hot water tank size, and cold water tank size for variable cooling demand. In this study, it is assumed that at least $95 \%$ of the design cooling demand for the design day has to be met by the proposed cooling system so that the average temperature of the hot water tank is between 55 and $95^{\circ} \mathrm{C}$.

The performance of the system has been investigated for different areas of the solar collecting field and different volumes of the hot water tank with cold water tank volume of its initial design value. The solar collecting area changes from 46 to $64 \mathrm{~m}^{2}$ with the step of $2 \mathrm{~m}^{2}$, and the volume of the hot water tank changes from 1 to $10 \mathrm{~m}^{3}$ with $0.5 \mathrm{~m}^{3}$ step. As shown in Fig. 7, the average temperature of the hot water storage tank decreases with the increase in the hot tank volume and specifically, it decreases gradually with tank size from 3 to $10 \mathrm{~m}^{3}$ for all solar collecting areas. The shaded area in the figure shows the permissible solar collecting areas and hot water tank volumes for average temperature of hot tank less than $95^{\circ} \mathrm{C}$. Figure 8 indicates that the cooling load that can be met by the cooling system increases with hot tank volume until volume of $1.5 \mathrm{~m}^{3}$ for all solar collector areas and then it is almost constant for the most of them. The shaded area shown in the figure shows the permissible system variables that can meet 


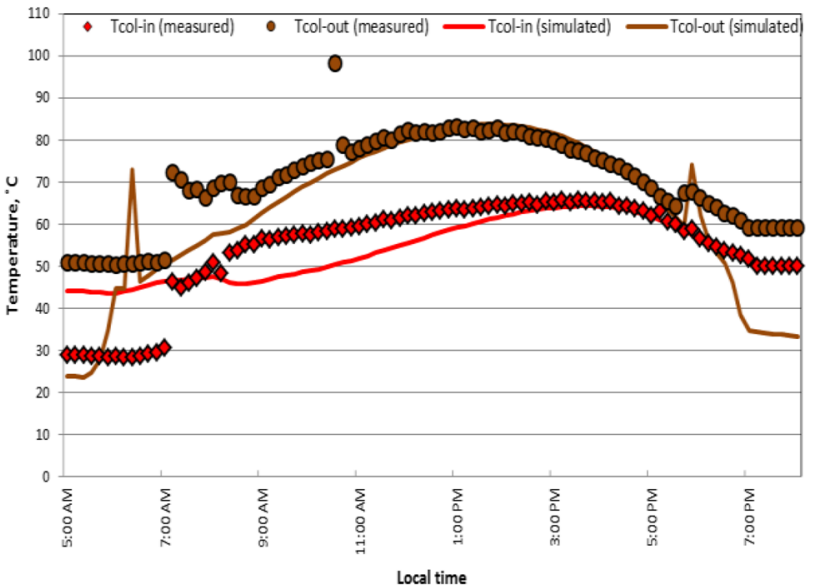

(a) Inlet and outlet water temperatures of the collector field.

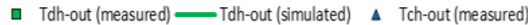

—Tch-out (simulated) $\quad$ - Tc-out (measured) -Tc-out (simualted)

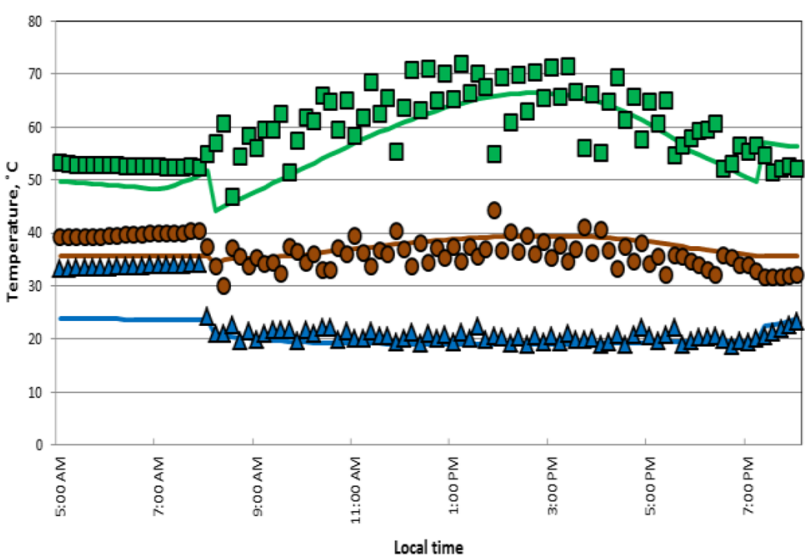

(c) Outlet water temperatures of the water-silica gel adsorption chiller.

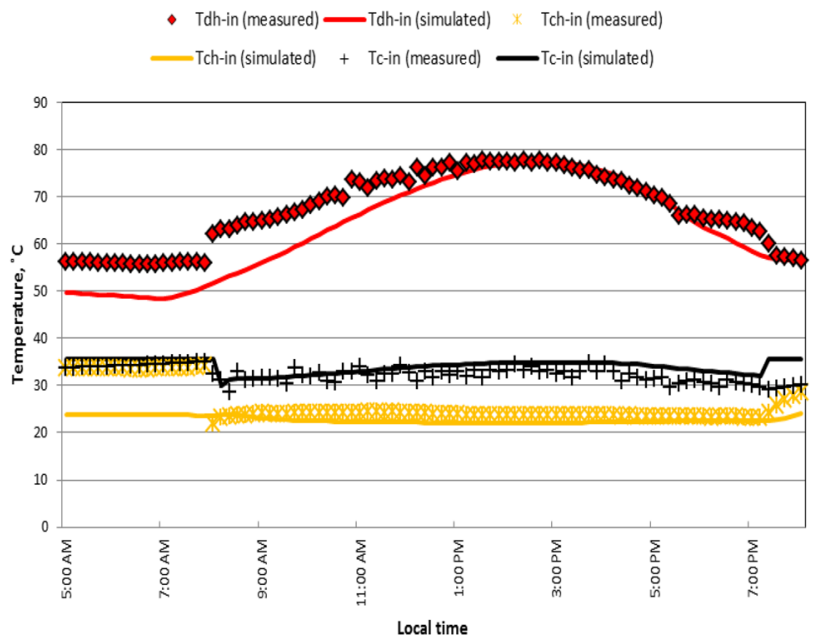

(b) Inlet water temperatures of the water-silica gel adsorption chiller.

- Tch-1-in (measured) —Tch-1-in (simulated) a Tch-1-out (measured) —Tch-1-out(simulated)

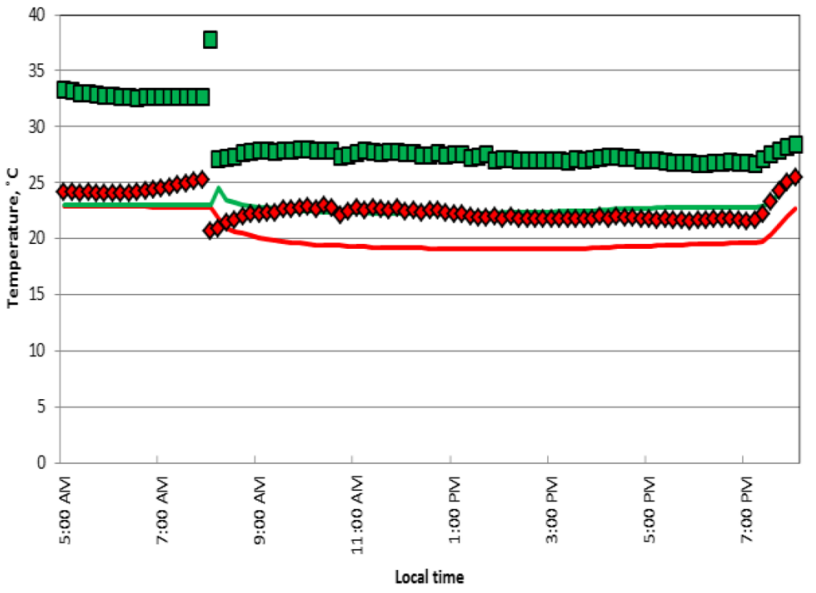

(d) Inlet and outlet temperatures of the fan coil units (water side).

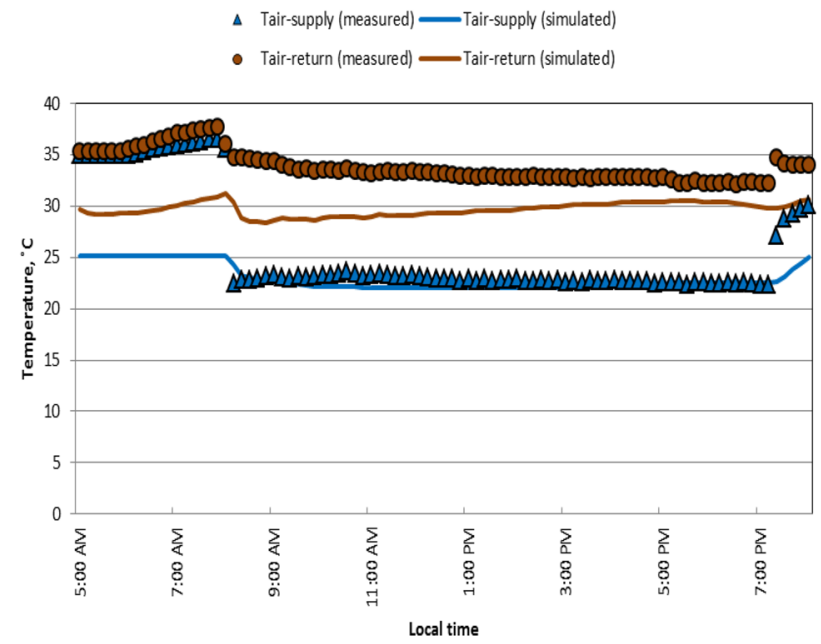

(e) Supply and return temperatures of the fan coil units (air side).

Fig. 6 Comparison between the measured and simulated inlet and outlet water temperatures of the main components of proposed system 
Table 1 Average absolute relative error (AARE) of the main parameters of the simulation model

\begin{tabular}{llll}
\hline System model parameter & AARE (\%) & System model parameter & AARE (\%) \\
\hline Inlet water temperature of solar collector & 6.5 & Outlet chilled water temperature of chiller & Outlet cooling water temperature of chiller \\
Outlet water temperature of solar collector & 7 & Inlet chilled water temperature of fan coil unit & 6.4 \\
Inlet hot water temperature of chiller & 5.2 & Outlet chilled water temperature of fan coil unit & 11.9 \\
Inlet chilled water temperature of chiller & 5.8 & Supply air temperature of fan coil unit & 17.3 \\
Inlet cooling water temperature of chiller & 5.4 & Return air temperature of fan coil unit & 2.8 \\
Outlet hot water temperature of chiller & 8.6 & & 10.5 \\
\hline
\end{tabular}

Fig. 7 Effect of the volume of the hot water tank on its average temperature for solar collecting field of different areas

Fig. 8 Effect of the volume of the hot water tank on the cooling load percentage for solar collecting field of different areas
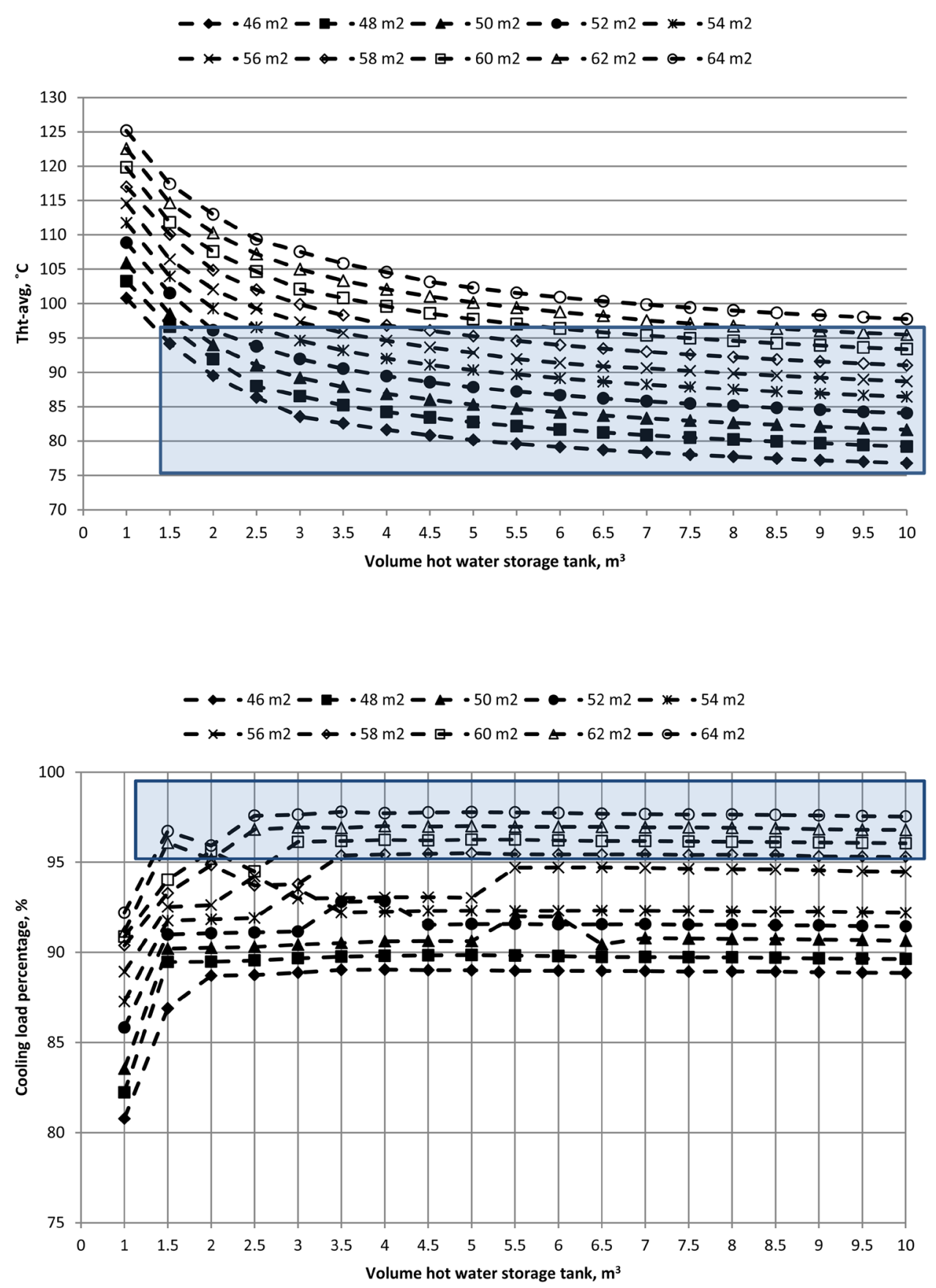

SN Applied Sciences A SPRINGER NATURE journa 
more than $95 \%$ of the design cooling demand. Based on these two shaded areas, another parametric study has been performed including solar collecting areas: 58,60 , and $62 \mathrm{~m}^{2}$, hot water tank volume from 5 to $7 \mathrm{~m}^{3}$ with step $0.5 \mathrm{~m}^{3}$, and cold water tank size from 0.8 to $1.2 \mathrm{~m}^{3}$ with step $0.1 \mathrm{~m}^{3}$. From this study, solar collecting filed of $58 \mathrm{~m}^{2}$ in area with hot water tank of $5.5 \mathrm{~m}^{3}$ in volume and a cold water tank of $1 \mathrm{~m}^{3}$ in volume are the optimal design parameters of the proposed fully solar powered adsorption cooling system for the investigated site.

\section{System performance}

The performance of the proposed solar cooling system with the optimal design parameters has been conducted for the cooling season. Figure 9 shows the temperatures of the adsorption chiller for 3 days: the design day, day before and day after (June 18, 19, and 20). As shown in the figure, during the system operation, once the temperature of the top of the hot water tank reaches $95^{\circ} \mathrm{C}$ the mixing valve-used for avoiding high water temperatures-works, and the driving hot water temperature inlet to the chiller sharply decreases and vice versa. However, the inlet-driving hot water temperature exceeds $95^{\circ} \mathrm{C}$ and reaches to about $96{ }^{\circ} \mathrm{C}$ from 1:50 pm to $4: 40 \mathrm{pm}$ for the design day as an example. The chilled water temperature leaving the chiller to the cold water tank is around between 17 and $18^{\circ} \mathrm{C}$. This temperature is slightly high, and this can be attributed to that the temperature of the cooling water coming from the cooling tower to the chiller is high and reaches to about $34.5^{\circ} \mathrm{C}$. Figure 10 shows the comfort conditions of the air conditioned zone. For the design day and during the operation period which is extended from
8 am to $11: 10 \mathrm{pm}$, the dry bulb temperature of the air conditioned zone is higher than the design value $\left(26^{\circ} \mathrm{C}\right)$. It ranges between 26.9 and $28.9{ }^{\circ} \mathrm{C}$. The relative humidity is also away from the design condition (50\%) and it ranges between 53.5 and $62.3 \%$. The proposed fully solar driven adsorption cooling system can meet about $85.7 \%$ of the cooling demand for the design day. For the entire cooling season, the system cannot meet the whole daily cooling demand for about $9.15 \%$ of the cooling season days.

The solar, absorbed, and driving heat energy rates for the successive 3 days are shown in Fig. 11. The daily solar energy incident upon the solar collecting field for the design day is $487.6 \mathrm{kWh}$ with a maximum rate of $61.8 \mathrm{~kW}$. The solar collecting field absorbs about $274.7 \mathrm{kWh}$ with daily collecting efficiency of about $56 \%$. The absorbed solar energy stored in the hot water tank is used for driving the adsorption chiller. The driving heat energy for the design day can drive the chiller from 8 am to $11: 10 \mathrm{pm}$ with energy rate ranges between 16.3 and $18.9 \mathrm{~kW}$ as shown in the figure. This driving energy makes the chiller produce about $113.3 \mathrm{kWh}$ chilling energy with energy rate around $7.35 \mathrm{~kW}$ which is stored in the cold water storage tank, as shown in Fig. 12. The cold water tank enables the system to extend the operation period of the cooling load circuit for about 110 min after switching off the chiller. Figure 13 describes the behavior of the adsorption chiller for the design day. The chilling power generated by the chiller just exceeds $8 \mathrm{~kW}$ at the start of the chiller, while during the steady operation it ranges between 7.14 and $7.53 \mathrm{~kW}$ and it reaches its maximum value at about $7 \mathrm{pm}$. Meanwhile, the COP ranges from 0.4 to 0.46 during the operation period with 0.41 daily values. The decline in the chiller COP value is attributed to the moderately high
Fig. 9 Temperatures of the silica gel-water adsorption chiller integrated in the proposed system

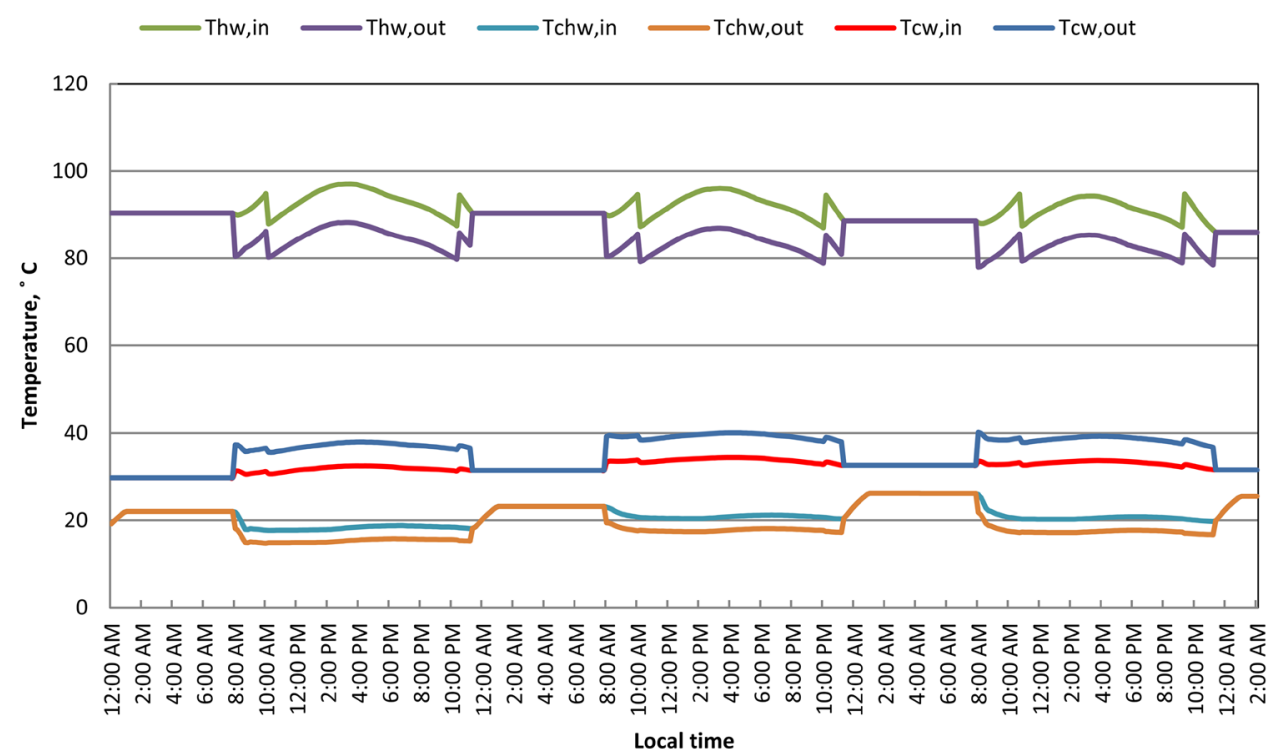

SN Applied Sciences 
Fig. 10 Conditions of the air conditioned zone

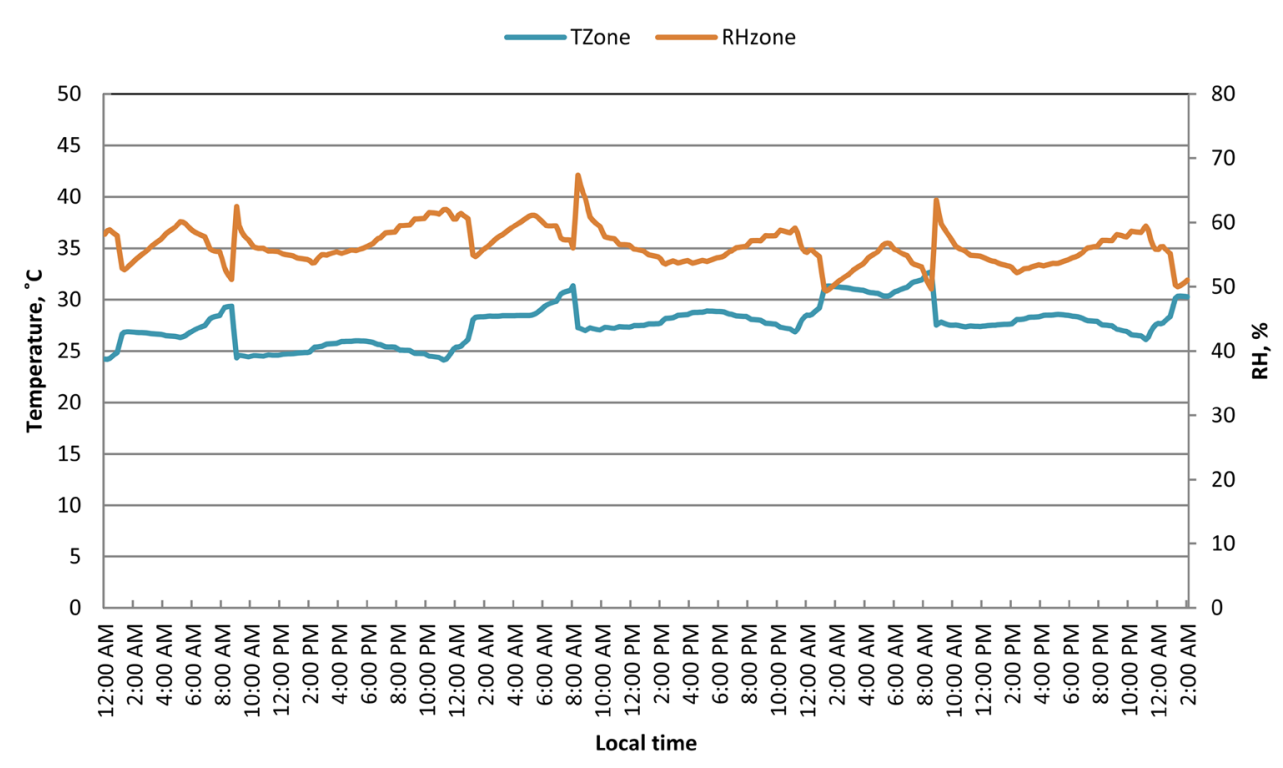

$\longrightarrow$ qsol $\longrightarrow$ qabs $\longrightarrow$ dh

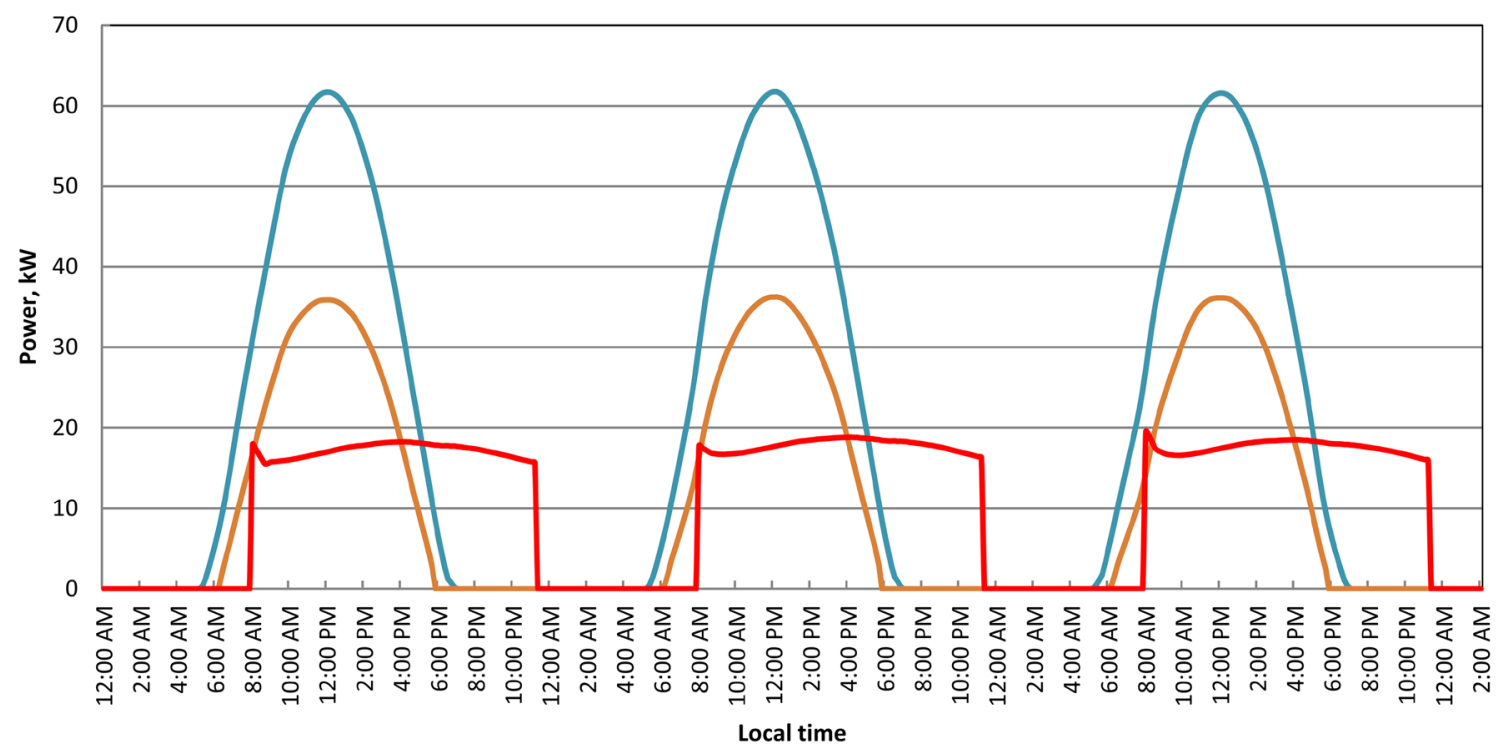

Fig. 11 Solar, absorbed, and driving heat energy rates of the proposed solar cooling system

value of the temperature of the cooling water coming to the chiller from the cooling tower.

Figure 14 shows the energies of the proposed solar cooling system for the months of the cooling season. For June as an example, the solar collecting field of the system receives about $14.52 \mathrm{MWh}$ and absorbs about 8.05 MWh. About 7.79 MWh of the energy absorbed by the solar collecting field is used for driving the adsorption chiller to make it produce about 3.24 MWh as chilling energy for meeting the cooling demand. As shown in
Fig. 4, the higher the driving heat energy, the higher the chilling energy generated by the chiller. The maximum value of the driving heat energy and chilling energy is achieved in July where the system can produce about 3.31 MWh chilling energy via using 7.87 MWh driving energy. Meanwhile, the lowest driving heat energy value during the cooling season and consequently, the chilling energy value are achieved in September where about $2.98 \mathrm{MWh}$ chilling energy can be produced by using $6.74 \mathrm{MWh}$ driving energy. 


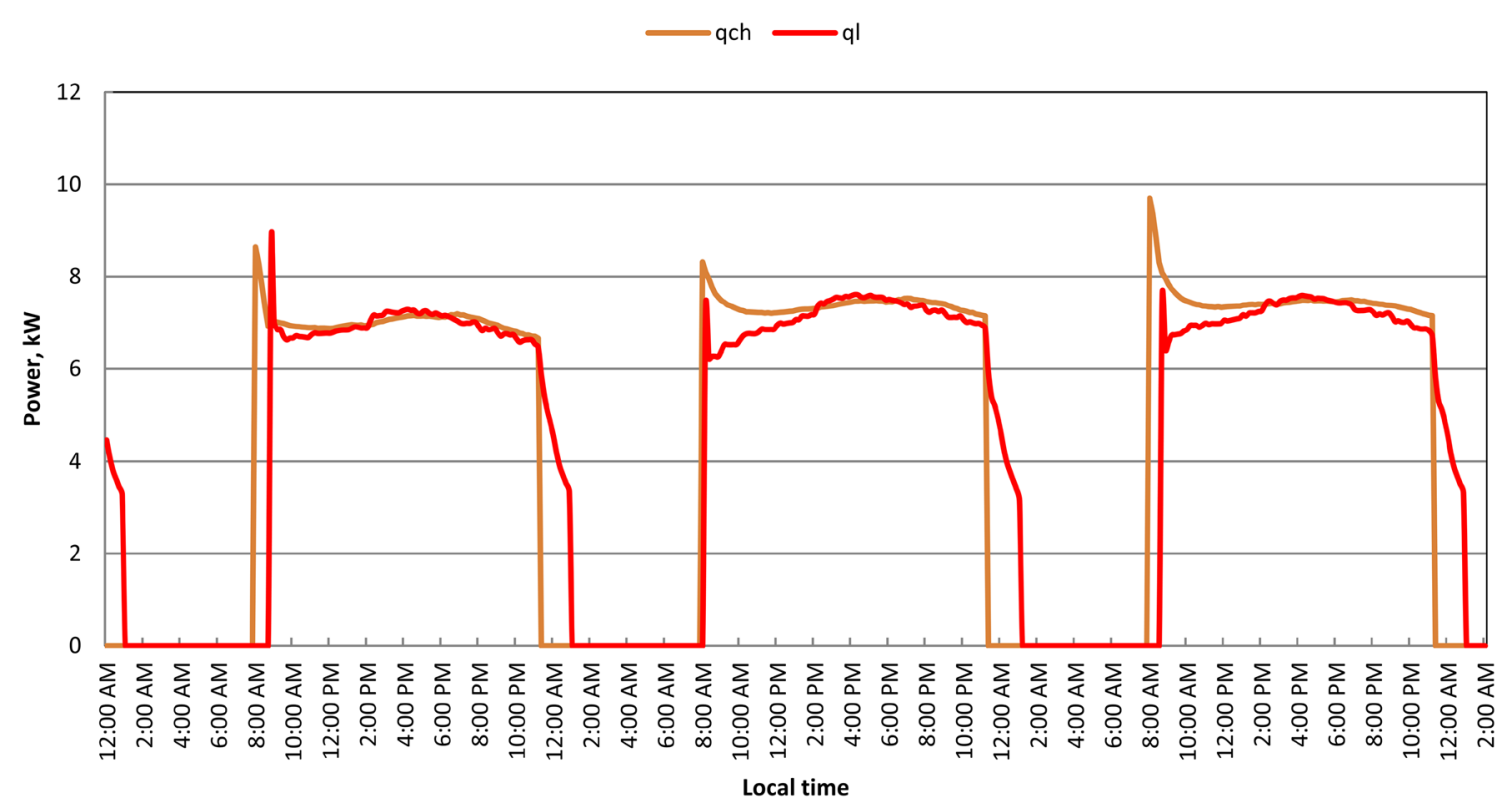

Fig. 12 Chilling and cooling load powers

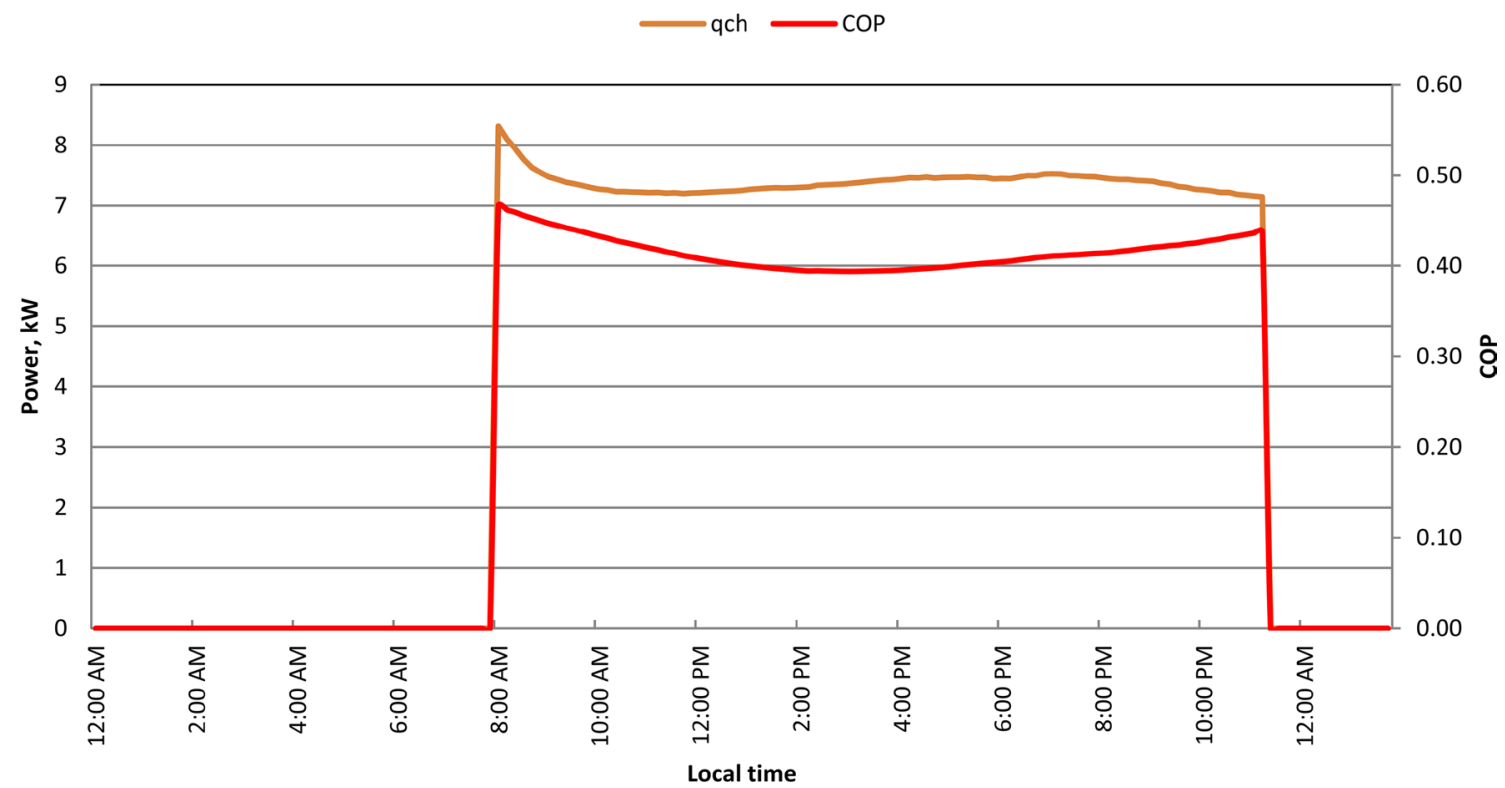

Fig. 13 Chilling power and COP of the adsorption chiller

\section{Conclusion}

The primary objective of this study is to identify the optimal design parameters of a fully solar-powered silica gel-water adsorption cooling system for residential buildings located in hot, arid areas as well as the system performance during the whole cooling season. For achieving the objective of this study, a parametric optimization based on a computer simulation has been performed on the system design parameters: solar collector area, hot water tank volume, and cold water tank volume. As a case study, the system was applied to Assiut City, Egypt which is distinguished by hot and arid weather conditions. As a dynamic simulation tool, TRNSYS program was used for executing the system dynamic simulation model. The parametric study shows that the optimal design variables of the proposed system are as follows: the optimal solar 


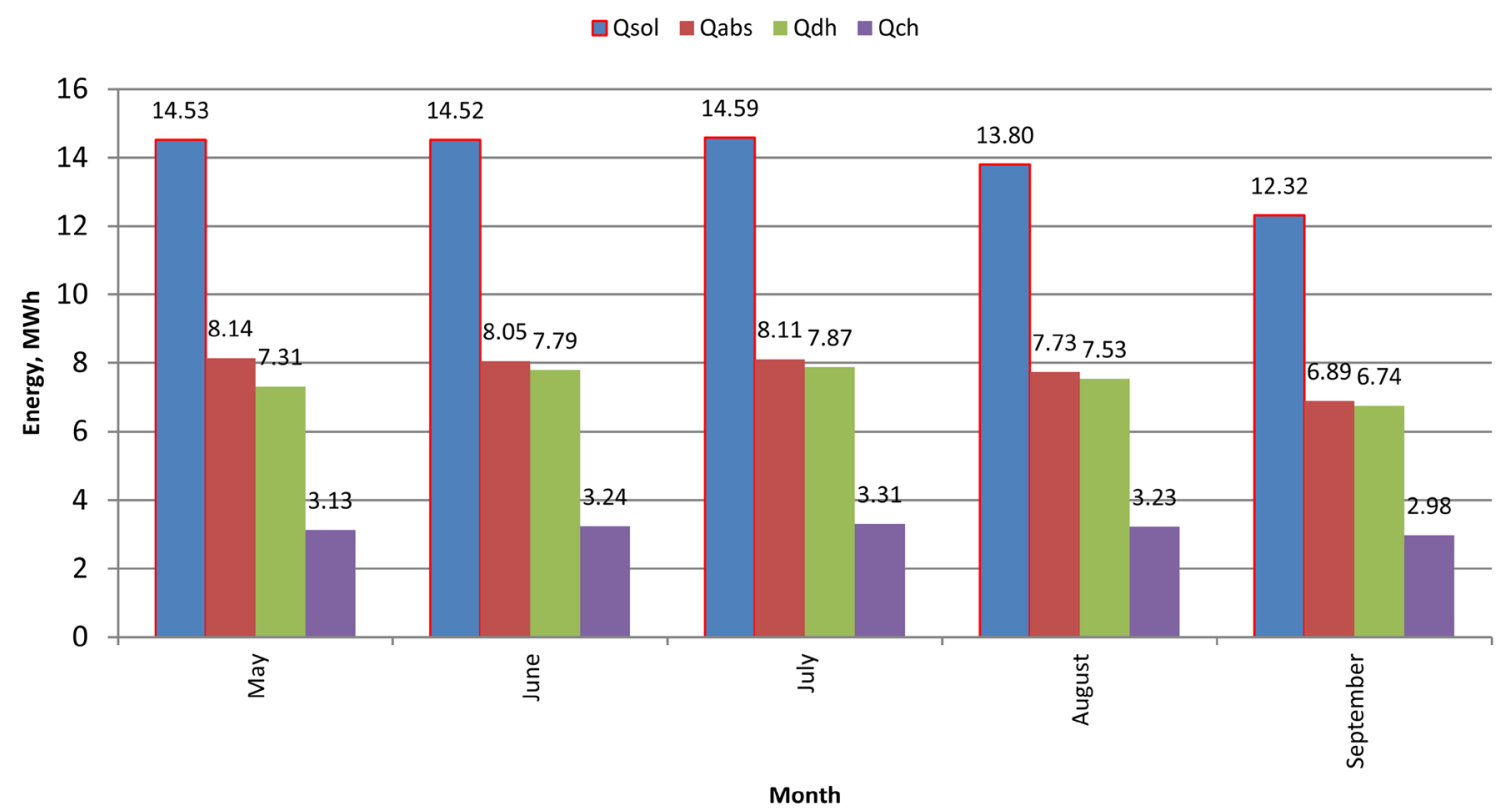

Fig. 14 Energies of the proposed system for the cooling season

collecting area is $58 \mathrm{~m}^{2}$ with $5^{\circ}$ tilt angle facing south, the optimal hot storage tank volume is $5.5 \mathrm{~m}^{3}$ and the optimal cold storage tank is $1 \mathrm{~m}^{3}$.

The performance of the proposed adsorption cooling system with the optimal design parameters for the design day has also been investigated. The operation of the dynamic simulation shows that the inlet-driving hot water temperature exceeds $95^{\circ} \mathrm{C}$ and reaches to about $96^{\circ} \mathrm{C}$ for about $2.7 \mathrm{~h}$. Moreover, the chilled water temperature leaving the chiller is around between 17 and $18^{\circ} \mathrm{C}$ with moderately high cooling water temperature reaches to about $34.5^{\circ} \mathrm{C}$. This makes the system unable to achieve the indoor thermal design conditions for the design day. However, the system can meet the cooling demand in most days of the cooling season except for about $9.15 \%$ representing extreme hot days. The dynamic simulation also shows that during the design day, the proposed system achieves daily collecting efficiency of about $56 \%$ and can produce chilling energy of $113.3 \mathrm{kWh}$ with $7.35 \mathrm{~kW}$ energy rate and daily COP of about 0.41 . In addition, the cold storage tank enables the system to extend the operation period about $110 \mathrm{~min}$ after switching off the chiller.

Acknowledgements The authors would like to acknowledge the funding of the Science and Technology Development Fund (STDF), Egyptian Ministry for Scientific Research within the Project "SolarDriven Adsorption Cooling for Residential Air-Conditioning - System Evaluation and Comparison to Conventional Chiller" as cooperation between the Faculty of Engineering, Assiut University, Egypt and Fraunhofer Institute for Environmental, Safety and Energy, Technology (UMSICHT), Germany.

\section{Compliance with ethical standards}

Conflict of interest The authors declare that they have no conflict of interest.

\section{References}

1. Alahmer A, Wang X, Al-Rbaihat R, Alam KCA, Saha BB (2016) Performance evaluation of a solar adsorption chiller under different climatic conditions. Appl Energy 175:293-304

2. Alam KCA, Saha BB, Akisawa A (2013) Adsorption cooling is driven by solar collector: a case study for Tokyo solar data. Appl Thermal Eng 50(2):1603-1609

3. Balaras CA, Grossman G, Henning HM, Infante Ferreira CA, Podesser E, Wang L, Wiemken E (2007) Solar air conditioning in Europe-an overview. Renew Sustain Energy Rev 11(2):299-314

4. Best R, Rivera W (2015) A review of thermal cooling systems. Appl Thermal Eng 75(22):1162-1175

5. Chang WS, Wang CC, Shieh CC (2009) Design and performance of a solar-powered heating and cooling system using silica gel/water adsorption chiller. Appl Thermal Eng 29(10):2100-2105

6. Choudhury B, Chatterjee PK, Habib K, Saha BB (2017) Performance investigation of a solar heat driven adsorption chiller under two different climatic conditions. J Inst Eng India Ser C 99(3):347-354

7. Choudhury B, Saha BB, Chatterjee PK, Sarkar JP (2013) An overview of developments in adsorption refrigeration systems towards a sustainable way of cooling. Appl Energy 104:554-567

8. Duffie JA, Beckman WA (1991) Solar engineering of thermal processes, 2nd edn. Wiley, New York

9. El Fadar A, Mimet A, Azzabakh A, Pérez-García M, Castaing J (2009) Study of a new solar adsorption refrigerator powered by parabolic trough collector. Appl Thermal Eng 29:1267-1270 
10. El Fadar A, Mimet A, Pérez-García M (2009) Study of an adsorption refrigeration system powered by parabolic trough collector coupled with a heat pipe. Renew Energy 34(10):2271-2279

11. El-Sharkawy II, AbdelMeguid H, Saha BB (2014) Potential application of solar powered adsorption cooling systems in the Middle East. Appl Energy 126(1):235-245

12. Ferreira Leite AP, Belo FA, Martins MM, Riffel DB (2011) Central air conditioning based on adsorption and solar energy. Appl Thermal Eng 31(1):50-58

13. Lu Z, Wang R, Xia Z (2013) Experimental analysis of an adsorption air conditioning with micro-porous silica gel-water. Appl Thermal Eng 50(1):1015-1020

14. Lu ZS, Wang RZ, Xia ZZ, Lu XR, Yang CB, Ma YC, Ma GB (2013) Study of a novel solar adsorption cooling system and a solar absorption cooling system with new CPC collectors. Renew Energy 50:299-306

15. Mitra S, Thu K, Saha BB, Dutta P (2017) Performance evaluation and determination of minimum desorption temperature of a two-stage air cooled silica gel/water adsorption system. Appl Energy 206:507-518

16. Reda AM, Ali AHH, Taha SI, Morsy MG (2017) Performance of a small scale solar-powered adsorption cooling system. Int J Green Energy 14(1):75-85

17. Reda AM, Ali AHH, Morsy MG, Taha IS (2016) Design optimization of a residential scale solar driven adsorption cooling system in upper Egypt based. Energy Build 130(15):843-856
18. Wang RZ, Oliveira RG (2006) Adsorption refrigeration-an efficient way to make good use of waste heat and solar energy. Prog Energy Combust Sci 32(4):424-458

19. Younes MM, El-Sharkawy II, Kabeel AE, Saha BB (2017) A review on adsorbent-adsorbate pairs for cooling applications. Appl Thermal Eng 114:394-414

20. Zhai H, Dai YJ, Wu JY, Wang RZ (2009) Energy and exergy analyses on a novel hybrid solar heating, cooling and power generation system for remote areas. Appl Energy 86(9):1395-1404

21. Zhai XQ, Wang RZ (2009) A review for absorption and adsorption solar cooling systems in China. Renew Sustain Energy Rev 13(6-7):1523-1531

22. Zhai $X Q$, Wang RZ (2009) Experimental investigation and theoretical analysis of the solar adsorption cooling system in a green building. Appl Thermal Eng 29(1):17-27

23. Zhai XQ, Wang RZ, Wu JY, Dai YJ, Ma Q (2008) Design and performance of a solar-powered air-conditioning system in a green building. Appl Energy 85(5):297-311

Publisher's Note Springer Nature remains neutral with regard to jurisdictional claims in published maps and institutional affiliations. 